\title{
Literature-Based reading material for EFL students: a case of Indonesian Islamic University ${ }^{1}$
}

\author{
Dedi Irwansyah - Burhan Nurgiyantoro - Sugirin
}

DOI: 10.18355/XL.2019.11.03.03

\begin{abstract}
This study presents an overview of literature-based reading materials for students of English as a foreign language (EFL) at Islamic universities in Indonesia. It includes an assessment of the materials by experts in the field, EFL practitioners at Islamic universities, and students of the English department. The developed materials describe the aims, objectives, methodology, topics, tasks, sequence, worksheet, and assessment procedure. The assessment of the materials is conducted qualitatively, through questionnaire and interview, and quantitatively through an experimental design. The purposes of this study are: (1) to develop literature-based reading materials for EFL students, (2) to investigate whether the developed materials are acceptable according to the experts' and practitioners' assessment, and (3) to investigate whether the materials are effective for the students. Findings indicate that the materials are well-rated by the experts and the practitioners particularly related to such aspects as text and topic, practicality, novelty, and task variation. The use of literary texts from Western, Indonesian, and Islamic tradition increases the acceptability of the materials. The small-scale experimental design of the research also confirms a significant difference between the students taught with literature-based reading materials and those taught with non-literature-based materials. The students of the experimental group also find the materials contextual and valuable.
\end{abstract}

Key words: literature-based instruction, reading, EFL student, materials development, Islamic University

\section{Introduction}

A recent study shows that Indonesian students have poor reading skills both in their mother tongue and in a foreign language (Richards, 2015: 443). The results of international assessments like Program of International Student Assessment (PISA) and Progress in International Reading Literacy Study (PIRLS) also confirm that Indonesian students' reading skills are among the lowest in the world. This phenomenon has something to do with the reading of literary texts. Alwasilah (2014: 209) notes the decreasing amount of

\footnotetext{
${ }^{1}$ The earlier version of this article is a part of my Ph.D dissertation submitted to Yogyakarta State University in 2018 entitled "Developing a LiteratureBased Reading Instructional Model for Students of the English Department at Islam-Affiliated University". I express my grateful thanks to Professor Burhan Nurgiyantoro and Professor Sugirin for their valuable comments and suggestions in its earlier version. However, I take responsibility for all shortcomings found in this article.
} 
literary texts read by students in Indonesia while at the same time students in other developed countries are required to read 5 to 32 literary texts per year.

The use of literary texts to teach a language, first or second language, in general, and to teach reading in particular, has long been considered to be appropriate for fluent readers and lower readers. Although the literature is potential for reading skill enhancement (Stern, 1991: 333), and value inculcation (Soeratno, 2005: 380; Zuchdi, et al., 2013: 39; Dewi, 2016: 12), little is known how it is utilized to teach English in the Indonesian Islamic university context.

Related researches have shown that literature-based materials help Indonesian secondary level students to build their linguistic and communicative skills as well as cultural understanding of their own and others' (Retnaningdyah, 2010: 12). At the university level, Puspitasari (2016:58) reports that the use of simple short story as preliminary materials helps the implementation of the literature-based approach.

The present research tries to go beyond by developing and testing literaturebased reading materials for Indonesian Islamic university. The particularity of the research setting will help delineate the use of various sources of literary texts (western, Indonesian, and Islamic traditions) within the approach of teaching with literature in an EFL reading class.

\section{Literature review}

A literary text is an aesthetic object which is commonly characterized by intertextuality and foregrounding language (Culler, 2008: 28-33). It refers to rule-governed genres or text types like poetry, song, fiction, drama, essay, biography, philosophical and religious texts, etc. (Maley, 2012; 302). Its domains cover religious, social, and personal aspects of human life (Moody, 1971: 4). It serves as a repository of moral and spiritual guidance (Showalter 2012: 22). Literature could be any text as long as it provides readers with aesthetic feelings.

\section{Literature-based reading instruction}

The term refers to the use of literature as the basis for classroom activities and tasks. It is based on the reader response theories in which 'the finding of meanings involves both the author's text and what the reader brings to it' (Rosenblatt, 2005: 30). Reader's prior knowledge and experience are central to a literature-based reading program. Vacca, et.al., (2006: 47) hold that a literature-based instruction might be implemented through some strategies: (1) students are offered to personally select the literary texts to read, (2) a group of students is conditioned to read and respond to the same of literary text, and (3) students are assigned to read different texts with similar themes and then discuss the insights within the texts. It is worth noting that a literary text is a distinctive mode of communication that requires both efferent and aesthetic reading strategies (Cox, 2012: 2-3). Thus, the information within the texts and the association, feeling, and attitude toward the ideas within the text are inseparable ingredients of the literary text reading.

XLinguae, Volume 13, Issue 3, June 2019, ISSN 1337-8384, eISSN 2453-711X 


\section{Literature-based materials}

The literary texts to be used in the EFL class should be selected on the basis of students' needs, cultural background, and language level (Collie \& Slater, 1994: 6); content and visual illustration (Vardell, et.al., 2006: 736); and moral aspect and cultural sensitivity (Maley, 2012: 307). It should also be supported by a suitable layout, font size, illustrations which are easy on the eye; background information about the historical or cultural setting; summary of the plot; glosses or explanation of difficult words or phrases; translation or bilingual editions with facing pages; audio and video versions of the text; and appropriate pre-reading activities. (Maley, 2008: 140-142). Once a literaturereading material is developed, some questions need to be answered, such as Have the materials met the desired objectives? Are the contents relevant to the students' context and needs? Are the language (lexis and grammar) and the length of the text in line with the students' literacy level? Do the visual aspects help convey the messages of the text? Are the formats of the materials easily used or performed by students and teachers? Are the materials performable in the available time allocation? (Asia/Pacific Cultural Centre for UNESCO (ACCU), 2001: 69).

\section{Content and sequencing}

The content and sequence of learning materials are principally designed by (1) environment which covers students' characteristics, teachers' qualification, and instructional situation; (2) needs which refer to the lacks, wants, and necessities; and (3) principles of teaching and learning. In the practical level, the materials are selected and sequenced based on units of progression or items which are used to monitor the progress of a course. These include words, grammar, language function, topics, themes, sub-skills, and so forth (Nation, Macalister, 2010: 70-73). Good learning materials should be equipped with a clear description of units and contents as well as relevant information such as time allotment and review session (Richards, 2001: 167). Alternatively, content can be sequenced following the principle of from here to there, from easy to difficult, and from familiar to unfamiliar (Alwasilah, 2014: 199).

\section{Worksheet}

Collie and Slater (1994: 38-51) argue that worksheets are designed to foster students' understanding of the language and the idea within a literary text. Typical worksheets include character worksheets which are commonly designed to highlight the characters; value judgment worksheets for eliciting moral and aesthetic issues; and language worksheets to emphasize words, grammar, literal meaning, and metaphorical meaning. Lazar (2009: 186) proposes four items of a worksheet: facts about the work such as title, author, genre, and year of publication; content like setting, plot, characters, and message; language pertaining to words and phrases that students have learned from the work; and students' personal opinion or evaluation about the work. 


\section{Assessment}

Richards (2015: 451-452) proposes Barret's five-level (L1-L5) taxonomy to assess reading, namely: L1: literal comprehension which focuses on the explicitly stated information ; L2: reorganization which is pertinent to organizing, analyzing, and synthesizing the explicitly stated information; L3: inferential comprehension which covers the combination of the explicitly stated information and reader's own opinion; L4: evaluation which pertains to judgments on values and worth; and L5: appreciation concerning with the reader's psychological and aesthetical responses toward the text. The taxonomy might be combined with Cox's (2012: 2-4) 'reader response questions and prompts' such as: What did you think of the story? What was your favorite part of the story? Has anything like this ever happened to you? Tell about it! Was there anything in the story you wondered about? If you were a character in the story, what would you say?

\section{Reading activities}

Lazar (2009: 84-86) elaborates literature reading activities into the prereading stage, while-reading stage, and post-reading stage. Pre-reading activities are aimed at helping students with the forthcoming cultural background, stimulating their interests in the literary works, and pre-teaching vocabulary. While-reading activities are designed to help students understand the plot, characters, difficult vocabulary, style, and language. Post-reading activities are intended to help students interpret the text and understand the narrative point of view. Richards (2015: 463) maintains that the post-reading stage often links reading skill with other skills such as writing and speaking.

\section{Contexts of literature-based instruction}

The literature-based instruction should take into account the global, national, and particular contexts. The global context is pertinent to postmethod pedagogy and the notion of the epistemic break. The former suggests that English teachers be sensitive to locality issues (Kumaravadivelu, 2012a: 11) while the latter challenges the teachers to design a contextually-relevant and culturally sensitive learning materials (Kumaravadivelu, 2012b: 25). National context refers to the Indonesian national context, which requires the incorporation of religious values, cultural values, and national pluralism into the existing instructional practices as regulated by the 2003 Educational Act, Article 4. Particular context refers to Islamic educational institution which seeks to integrate Islamic educational philosophy and tradition into the English language teaching.

It is worth noting that the Indonesian Islamic university is faced with two intriguing facts related to literature-based instruction. First, the use of English and American literature only could be problematic when it is not carefully handled (Toh, 2000: ii-iii; Ratna, 2008: 120; Rakhmat, 2009: 142). Second, Islamic literature has not been adequately explored in Indonesian Islamic universities (Muthari, 2016:6) although it has been playing a significant role in the training and education of Islamic values (Bayat \& Jamnia, 1994: 3). 


\section{Methodology}

This study applies a mixed-method strategy in that the researchers involve qualitative strategies, particularly questionnaire and interview, and quantitative strategy, experimental design, in data collection (Creswell, 2012: 543).

\section{Participants}

Three experts from Yogyakarta State University and five practitioners from three different Islamic universities in Indonesia (IAIN Metro, Universitas Muhammadiyah Metro, and IAIM NU Metro) assessed the developed literature-based reading materials. Sixty-six students of the English department at the State Islamic Institute of Metro academic year of 2016/2017 involved in the field testing through a nonequivalent controlgroup design.

\section{Procedure}

The literature-based reading material was developed in seven phases. First, researchers collected information through inventorying the existing reading materials. Second, researchers developed preliminary literature-based reading materials. Third, experts and practitioners assessed developed materials. Fourth, researchers revised the materials in tune with the suggestion from the experts and practitioners. Fifth, researchers implemented developed materials through an experimental design. Sixth, researchers interviewed students' representative of the experimental group related to the implementation of the developed materials. Seventh, the researchers revised the developed materials.

\section{Data analysis}

The qualitative data gained from the interview and questionnaire were audiorecorded, transcribed, coded, and subjected to content analysis. The quantitative data gained from the pretest and posttest administration are analyzed using the t-test when normality and homogeneity assumptions are met, and the Mann-Whitney U test when the normality or homogeneity assumptions are not satisfied. The statistical analysis is conducted by utilizing the Statistical Package for Social Science (SPSS) software.

\section{Results}

\section{Literature-based reading materials for EFL students}

Before the materials development is the existing materials inventory covering three commercially-developed reading materials and four lecturer-generated reading materials used by five reading lecturers at three Islamic universities in Indonesia. The materials are assessed by the practitioners with recapitulation presented in Table 1 . 
Table 1: Recapitulation of the existing materials assessment

\begin{tabular}{llccc}
\hline No. Items/Aspects & \multicolumn{4}{c}{ Percentage } \\
\cline { 2 - 5 } & SD & DA & A & SA \\
\hline 1. The content is relevant to: & & & & \\
\hline Islamic context & - & 40 & 40 & 20 \\
\hline Indonesian context & - & 20 & 80 & - \\
\hline International context & - & - & 40 & 60 \\
\hline Students' language proficiency & - & 20 & 40 & 40 \\
\hline Students' intellectual capacity & - & - & 80 & 20 \\
\hline 2. Linguistic appropriateness & & & & \\
\hline Vocabulary & - & 40 & 60 & - \\
\hline Grammar & - & 40 & 60 & - \\
\hline 3. The tasks are: & & & & \\
\hline Relevant & - & 40 & 40 & 20 \\
\hline$\quad$ Varied & - & 20 & 60 & 20 \\
\hline 4. The materials are sequenced from: & & & & \\
\hline Easy to difficult & - & 20 & 60 & 20 \\
\hline$\quad$ Familiar to unfamiliar & - & 20 & 40 & 40 \\
\hline 5. Presentation & & & & \\
\hline Pre-reading activities are interesting & - & 20 & 60 & 20 \\
\hline $\begin{array}{l}\text { While-reading activities are } \\
\text { appropriate }\end{array}$ & - & 20 & 40 & 40 \\
\hline Post-reading activities are productive & - & 40 & 40 & 20 \\
\hline
\end{tabular}

6. Format

\begin{tabular}{llrrc}
\hline The title is suitable & - & - & 100 & - \\
\hline Visual illustration is adequate & - & 40 & 40 & 20 \\
\hline Layout is interesting & - & 40 & 40 & 20 \\
\hline Font size is appropriate & - & - & 80 & 20 \\
\hline
\end{tabular}

$\mathbf{S D}=$ Strongly disagree, or strongly irrelevant, or strongly inappropriate

DA = Disagree, or irrelevant, or inappropriate

$\mathbf{A}=$ Agree, or relevant, or appropriate

appropriate

SA = Strongly agree, or strongly relevant, or strongly

The sub-items or sub-aspects categorized as DA (disagree/irrelevant /inappropriate) in Table 1. need development. It implies that the developed literature-based reading materials should emphasize, among other things, the Islamic context, vocabulary and grammar appropriateness, task 
meaningfulness, productive post-reading activities, visual illustration, and interesting layout.

In tune with the above inventory, literature-based reading material is developed for EFL students of Indonesian Islamic universities. The material is equipped with such components as aims, objectives, methodology, tasks, topics, language content, sequence, worksheet, and assessment.

Aims. The primary aim of the literature-based reading materials is to help students: develop the skills of reading English; stimulate the interests in literature; and enhance the appreciation of international, national, and Islamic values. While the first point deals with the aim of all reading programs, the second and third points accommodate the interest in the use of literature for English language teaching, the notion of character education as it is emphasized by the existing Indonesian educational policy, and the need of integrating Islamic values into a reading program.

Objectives. The objectives of the literature-based reading are derived from the five levels (L1-L5) of reading comprehension proposed in Barrett's taxonomy ranging from comprehending detail information to giving psychological and aesthetical responses toward the texts.

Methodology. The approach taken is literature as resource or 'teaching with literature' in that literary texts are used to improve students' reading skills and to help them grow personally and socially. The teaching method is underpinned by the basic principle of Contextual Teaching and Learning (CTL), that is utilizing and connecting the materials with students' linguistic, personal, social, cultural, and spiritual contexts.

Tasks. The tasks are designed around the objectives. One objective might consist of more than one task. The tasks serve as the basis to state the indicators of achievement. Figures 2, 3, 4, 5, 6 include the configuration of the tasks in tuned with the comprehension levels, objectives, and indicators.

Table 2: Literal comprehension's objectives, tasks, and indicators

\begin{tabular}{l|l|l}
\hline \multicolumn{2}{l}{ Level 1: literal comprehension } \\
\hline Objective (s) & $:$ & $\begin{array}{l}\text { (1) recognizing detail information explicitly stated in } \\
\text { the text; (2) recalling detail information explicitly } \\
\text { stated in the text. }\end{array}$ \\
\hline Tasks & $:$ & $\begin{array}{l}\text { (1) answering questions that cover the key details of } \\
\text { the story; (2) identifying adjectives that describe the } \\
\text { characters; (3) answering multiple-choice questions on } \\
\text { difficult vocabulary; and (4) putting events in order. }\end{array}$ \\
\hline Indicators & $:$ & $\begin{array}{l}\text { students are able to: (1) answer WH-questions based on } \\
\text { the story; complete sentences related to key details of } \\
\text { the story; (2) identify the adjectives that best describe } \\
\text { the characters; (3) answer a multiple-choice questions } \\
\text { on difficult vocabulary; and (4) put the events in the } \\
\text { story into a correct order. }\end{array}$ \\
\hline
\end{tabular}


Table 3: Reorganization's objectives, tasks, and indicators

\begin{tabular}{l|l|l}
\hline \multicolumn{2}{l}{ Level 2: reorganization } \\
\hline Objective(s) & $:$ & $\begin{array}{l}\text { organizing, analyzing, and synthesizing the information } \\
\text { which has been explicitly stated in the text. }\end{array}$ \\
\hline Tasks & $:$ & $\begin{array}{l}\text { (1) paraphrasing the story; (2) dividing the story into } \\
\text { several parts; and (3) organizing words. }\end{array}$ \\
\hline Indicators & $:$ & $\begin{array}{l}\text { students are able to: (1) tell the story in their own } \\
\text { words; (2) divide the story into beginning, middle, and } \\
\text { end; (3) match the words to their definition, synonym, } \\
\text { or antonym; (4) identify the part of speech, meaning, } \\
\text { related words, antonyms/ synonyms; (5) fill in the } \\
\text { correct words into a given text. }\end{array}$ \\
\hline
\end{tabular}

Table 4: Inferential comprehension's objectives, tasks, and indicators

\begin{tabular}{l|l|l}
\hline \multicolumn{2}{l}{ Level 3: inferential comprehension } \\
\hline Objective(s) & $:$ & $\begin{array}{l}\text { combining the explicitly stated information in the text } \\
\text { with the reader's own opinion. }\end{array}$ \\
\hline Tasks & $:$ & $\begin{array}{l}\text { (1) inferring character trait; (2) ranking the characters; } \\
\text { (3) inferring certain linguistic aspects; (4) discussing } \\
\text { possible themes; and (5) discussing symbolic meaning. }\end{array}$ \\
\hline Indicators & $:$ & $\begin{array}{l}\text { students are able to: (1) infer the character traits from } \\
\text { the extracts of the story; (2) rank the characters in term } \\
\text { of 'the most' and 'the least'; (3) infer certain phrases in } \\
\text { the story; (4) infer certain sentences in the story; (5) } \\
\text { exploit unusual linguistic features; (6) identify the } \\
\text { appropriate themes of the story or the text; and (7) note } \\
\text { down the words or phrases with symbolic meaning. }\end{array}$ \\
\hline
\end{tabular}

Table 5: Evaluation's objectives, tasks, and indicators

\begin{tabular}{l|c|l}
\hline \multicolumn{2}{l}{ Level 4: evaluation } \\
\hline Objective(s) & $:$ & $\begin{array}{l}\text { judging and deciding on the values and worth related to } \\
\text { the texts. }\end{array}$ \\
\hline Tasks & $:$ & $\begin{array}{l}\text { (1) writing a review of a story; (2) writing a synopsis of } \\
\text { a story; and (3) discussing the values found in the text. }\end{array}$ \\
\hline Indicators & $:$ & $\begin{array}{l}\text { students are able to: (1) write a review on certain } \\
\text { aspects of the story; (2) complete the self-access } \\
\text { worksheet; (3) write a summary of the story outlining }\end{array}$ \\
\hline \hline
\end{tabular}

XLinguae, Volume 13, Issue 3, June 2019, ISSN 1337-8384, eISSN 2453-711X 


\begin{tabular}{l|l|l}
\hline & $\begin{array}{l}\text { its plot; (4) identify the global or national or Islamic } \\
\text { values of the story; and (5) identify character education } \\
\text { values. }\end{array}$ \\
\hline
\end{tabular}

Table 6: Appreciation's objectives, tasks, and indicators

\begin{tabular}{l|c|l}
\hline \multicolumn{2}{l}{ Level 5: appreciation } \\
\hline Objective(s) & $:$ & $\begin{array}{l}\text { giving psychological and aesthetical responses toward } \\
\text { the texts }\end{array}$ \\
\hline Tasks & $:$ & $\begin{array}{l}\text { (1) imagining of being a character in the story; (2) } \\
\text { changing the point of view of the story; and (3) } \\
\text { demonstrating the text. }\end{array}$ \\
\hline Indicators & $:$ & $\begin{array}{l}\text { students are able to: (1) write a brief essay on being a } \\
\text { character in the story; (2) rewrite certain extracts of the } \\
\text { story by changing the point of view; (3) perform a role } \\
\text { play; and (4) read the text (poem) chorally. }\end{array}$ \\
\hline
\end{tabular}

Topics. The developed literature-based reading materials provide the topics which are closely related to the personal, social, cultural, and spiritual contexts of the students such as environment, noble character, heroism, friendship, self-empowerment, greed, bravery, peace, freedom, code of conduct, human and society, and love. The texts related to the topics are derived from a wide range of sources representing the Western, Indonesian, and Islamic traditions as presented in Table 7.

Table 7: Topic, title, category, and source of the developed materials

\begin{tabular}{|c|c|c|c|c|}
\hline No. & Topic & Title & Category & Source \\
\hline 1. & Environment & $\begin{array}{l}\text { The Prayer of the } \\
\text { Frog }\end{array}$ & Western & Mello (2015: 4-5) \\
\hline 2. & Noble character & Narcissus & Western & Coelho (1998) \\
\hline 3. & Heroism & $\begin{array}{l}\text { Umar and the } \\
\text { Hungry Woman }\end{array}$ & Islamic & $\begin{array}{l}\text { Brosh \& Mansur } \\
(2013: 78-80)\end{array}$ \\
\hline 4. & Friendship & $\begin{array}{l}\text { The Merchant and } \\
\text { the Christian } \\
\text { Dervish }\end{array}$ & Islamic & Shah (1967: 46-47) \\
\hline 5. & $\begin{array}{l}\text { Self- } \\
\text { empowerment. }\end{array}$ & Ilir-Ilir & Indonesian & $\begin{array}{l}\text { Doecke (2013: 14- } \\
\text { 15);Knauth (2010: } \\
\text { 173) }\end{array}$ \\
\hline 6. & Greed & $\begin{array}{l}\text { The Golden } \\
\text { Touch }\end{array}$ & Western & $\begin{array}{l}\text { Kasser \& Silverman } \\
(1986: 55-56) .\end{array}$ \\
\hline 7. & Bravery & $\begin{array}{l}\text { The Philosopher } \\
\text { and the Skipper }\end{array}$ & Islamic & $\begin{array}{l}\text { Bayat \& Jamnia } \\
(1994: 139-141)\end{array}$ \\
\hline 8. & Peace & Pasopati & Indonesian & $\begin{array}{l}\text { Knappert (1997: 43- } \\
45)\end{array}$ \\
\hline 9. & Freedom & $\begin{array}{l}\text { Moses and the } \\
\text { Shepherd }\end{array}$ & Islamic & $\begin{array}{l}\text { Rumi (2004: 165- } \\
168)\end{array}$ \\
\hline 10. & Code of conduct & $\begin{array}{l}\text { Moses and Al- } \\
\text { Khadir }\end{array}$ & Islamic & $\begin{array}{l}\text { Katheer (2001: 30- } \\
32 \text { ) }\end{array}$ \\
\hline
\end{tabular}




\begin{tabular}{|c|c|c|c|c|}
\hline \multirow[t]{2}{*}{11.} & \multirow{2}{*}{$\begin{array}{l}\text { Human and } \\
\text { society }\end{array}$} & Grown Up & Indonesian & Toh (2000: 14-19) \\
\hline & & Abou Ben Adhem & Western & $\begin{array}{l}\text { http://www.poemhu } \\
\text { nter.com/poem/abou } \\
\text {-ben-adhem/ }\end{array}$ \\
\hline 12. & Love & Sleeping Beauty & Western & $\begin{array}{l}\text { Rackhman } \\
\text { 206-211) }\end{array}$ \\
\hline
\end{tabular}

Language Content. The language content is designed to match the context of reading literature in a foreign language. Reading English literary texts are sometimes challenging due to the distinctive linguistic features and that the features often become barriers. Thus, to help students gain the fullest advantages of the reading activity, the literature-based reading materials offer the adapted version of each text. The adapted version uses more limited vocabularies and less complex structures to help students build schemata on the storyline or the gist of the forthcoming original version.

Sequence. The content is, hierarchically, sequenced based on text length, text variety, and task. Mostly, shorter stories are presented before longer stories except that of the last story as it is followed by the task of demonstrating the text. The shorter text of poems is inserted between the units that consist of short stories due to the text variety consideration. Figure 1 presents the content organization based on its length.

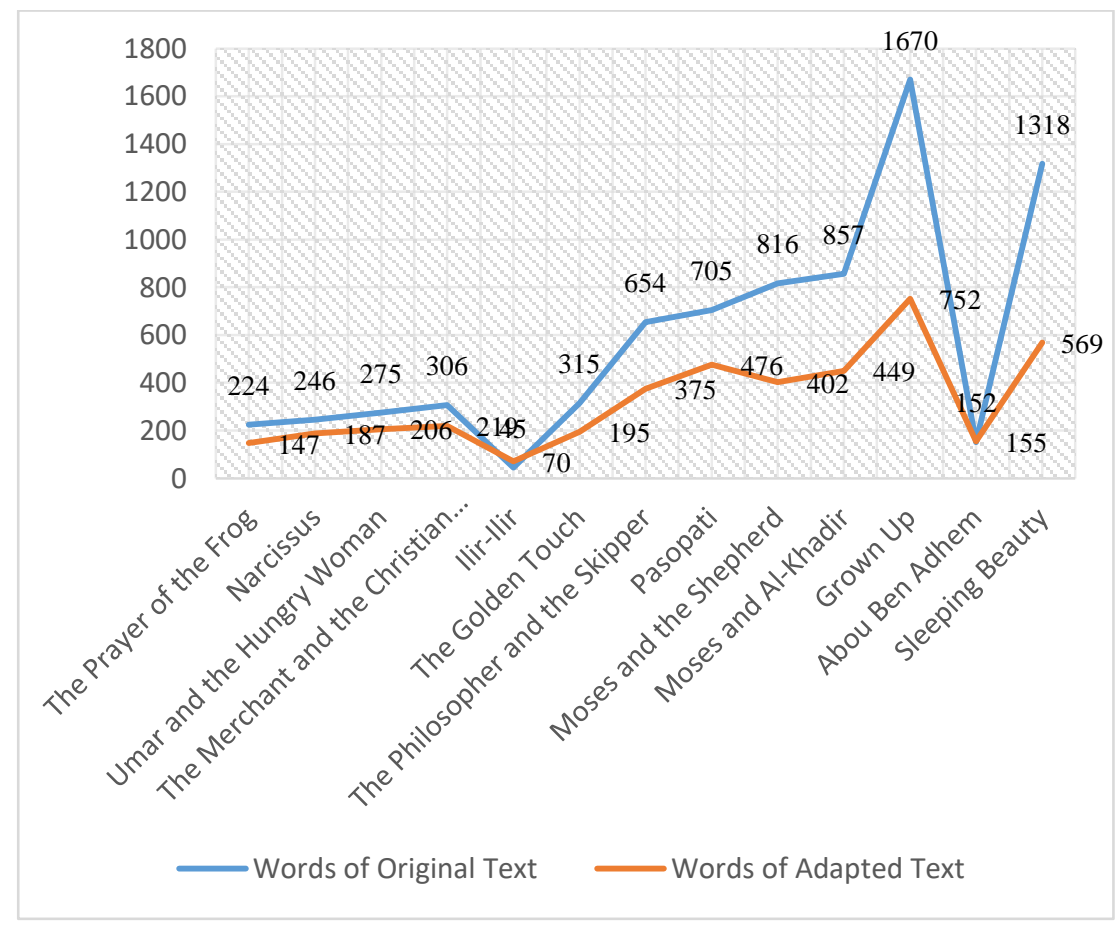

Figure 1: The content organization based on the text length 
Worksheet. To foster students' understanding of the literature-based materials, four types of worksheet are utilized. First, plot worksheet is used to help students understand the storyline. Second, character worksheet is designed to help students understand the traits of the characters. Third, value judgment worksheet is to help students elicit moral and aesthetic issues. Fourth, selfaccess worksheet is to help students with the content, language, and general information about the story. An example of the value judgment worksheet is presented in Figure 2.

\footnotetext{
Group:

Members:

Date: ...............................................

Read the story of The Prayer of the Frog. Discuss the moral or the value which you think most appropriate. You can write one of your own if none of the provided moral/value seems suitable. You will be asked to justify your choice.

The moral of the story is:

1. One should know the etiquette of offering a prayer

2. Allah did not create a thing aimlessly (al-Imran: 191).

3. Take time to pray. It is the greatest power on earth.

4. The love for all living creatures is a noble attribute of a human.

5. "Whoever is merciful even to a sparrow, Allah will be merciful to him on the Day of Judgment." (Prophetic tradition).

6. Your own:
}

\section{Relate the moral of the story with one of the following.}

[ ] Qur'anic revelation:

[ ] Prophetic tradition:

[ ] The opinion of the righteous predecessors:

\section{Figure 2: The value judgment worksheet}

Assessment. The developed literature-based reading materials utilize both traditional assessment and authentic assessment. The traditional assessment (multiple-choice test, matching task, gap-filling task) is mainly used within the scheme of efferent reading strategy and for the reading comprehension level of L1 to L3. Meanwhile, the authentic assessment (writing task and demonstration) is mainly utilized within the scheme of aesthetic reading strategy and for L4-L5 of the reading comprehension level.

\section{The experts' and practitioners' assessment}

The developed materials is assessed by three experts in the field of EFL reading, English literature instruction, and English instruction evaluation as well as by five EFL lecturers of three Islamic universities. The scale used is 2 (poor); 3 (Fair); 4 (good); and 5 (excellent). The recapitulation of the assessment is presented in Table 8 . 
Table 8: The assessment from experts and practitioners

\begin{tabular}{llcc}
\hline \multirow{2}{*}{ No. } & \multirow{2}{*}{ Aspects } & \multicolumn{2}{c}{ Mean } \\
\cline { 3 - 4 } & & Experts & Practitioners \\
\hline 1. & Worksheet usefulness & 4.33 & 4.80 \\
\hline 2. & Worksheet practicality & 4.00 & 4.40 \\
\hline 3. & The aims accuracy & 4.00 & 5.00 \\
\hline 4. & The method compatibility & 4.33 & 4.40 \\
\hline 5. & The text and topic variation & 4.67 & 4.40 \\
\hline 6. & The readability & 4.00 & 4.20 \\
\hline 7. & The language accuracy & 4.00 & 4.40 \\
\hline 8. & The practicality the materials & 4.67 & 4.40 \\
\hline 9. & The novelty the materials & 4.67 & 4.40 \\
\hline 9. & Task accuracy & 4.33 & 4.60 \\
\hline 10. & Task variation & 4.67 & 4.60 \\
\hline & & & \\
\hline
\end{tabular}

It is evident that most aspects of the developed literature-based reading materials are positively rated by experts and practitioners.

\section{The effectiveness of the developed materials}

Having been assessed, the developed materials are implemented through a small-scale experimental design.

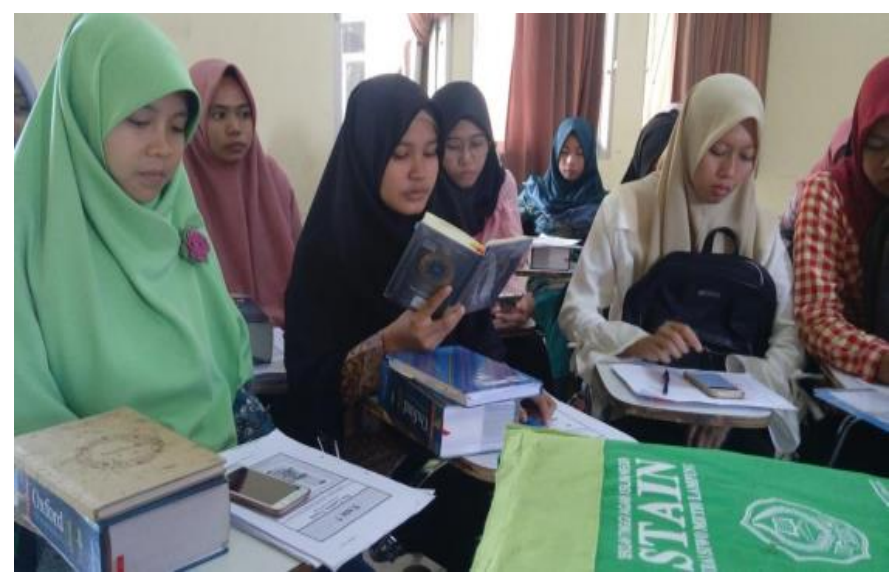

Figure 3: Pre-reading stage of the experimental group

Ten students of the experimental group are interviewed related to the implementation. The results of which are presented in Table 9. 
Table 9: Students' response to the literature-based reading materials

\section{Responses toward the usefulness of the reading materials:}

(1) local texts like Pasopati and Grown Up contain interesting historical and linguistic lessons $(\mathrm{S} 3 ; \mathrm{S} 2)$; the texts help students appreciate their own culture (S6); the texts are contextual (S8);

(2) the use of literary texts from various cultures (Indonesia, Islam, West) is enlightening (S2; S8);

(3) the story from Western culture, like Narcissus, reminds the students about the importance of appreciating others (S1);

(4) literary texts are stimulating because of the values embedded within (S9);

(5) a student knows the lyrics of Ilir-Ilir for a long time, but understands its meaning in this Reading class (S7);

(6) the story from the Islamic world, like Moses and Al-Khadir, broadens students' understanding of Islamic teaching and closely related to another course called 'Akhlak Tasawuf' (S4).

\section{Suggestions for improvement:}

(1) adding more exercises would be good (S1);

(2) the outdoor activity would be refreshing (S7);

(3) adding stories on the companions (şahābah) would be inspiring and useful (S8);

(4) more rewards for reading the materials would be stimulating (S1; S2; S5; S8; S10). $\mathrm{S}=$ Student

A quantitative evaluation of the implementation of the developed materials is also conducted through a nonequivalent control-group design in that both the experimental group and control group are subjected to pretest and posttest. The pretest results are presented in Table 10.

Table 10: Pretest scores recapitulation

\begin{tabular}{llccccc}
\hline No. & \multirow{2}{*}{ Group } & $\mathbf{N}$ & \multicolumn{5}{c}{ Scores } \\
\cline { 3 - 7 } & & $\begin{array}{c}\text { Minimum } \\
\text { Score }\end{array}$ & $\begin{array}{c}\text { Maximum } \\
\text { Score }\end{array}$ & Mean & $\begin{array}{c}\text { Std. } \\
\text { Dev }\end{array}$ \\
\hline 1. & Experimental & 33 & 33.3 & 80.0 & 62.4 & 16.2 \\
\hline 2. & Control & 33 & 26.7 & 86.7 & 60.2 & 16.8 \\
\hline
\end{tabular}

Since the pretest data fail to meet the assumption of normality, they are analyzed using a Mann-Whitney $U$ test. The result is presented in Table 11. 
Table 11: Mann-Whitney u test of pretest data

\begin{tabular}{lccl}
\hline Data Type & $\begin{array}{c}\text { Asymp. Sig. } \\
\text { (2-tailed) }\end{array}$ & $\boldsymbol{\alpha}$ & Remarks \\
\hline Pretest & .432 & .05 & Not Significantly different \\
\hline
\end{tabular}

It is evident that the scores of the experimental group are not statistically significantly higher than those of the control group as the Sig. (2-tailed) is higher than .05 .

A posttest is given to both the experimental and control group after the main field testing stage. Table 12 illustrates the recapitulation of the posttest scores.

Table 12: Posttest scores recapitulation

\begin{tabular}{ccccccc}
\hline No. & Group & $\mathbf{N}$ & \multicolumn{5}{c}{ Scores } \\
\cline { 3 - 7 } & & $\begin{array}{c}\text { Minimum } \\
\text { Score }\end{array}$ & $\begin{array}{c}\text { Maximum } \\
\text { Score }\end{array}$ & Mean & $\begin{array}{c}\text { Std. } \\
\text { Dev. }\end{array}$ \\
\hline 1. & Experimental & 33 & 45.8 & 91.7 & 71.7 & 11.5 \\
\hline 2. & Control & 33 & 35.4 & 89.6 & 60.3 & 14.7 \\
\hline
\end{tabular}

As the posttest data are normal and homogenous, a $t$-test is used to compare differences between the experimental group and control group, the result of which is presented in Table 13.

Table 13: Independent samples test

\begin{tabular}{|c|c|c|c|c|c|c|c|c|}
\hline & $\begin{array}{l}\text { Levene's } \\
\text { Test for } \\
\text { Equality of } \\
\text { Variances }\end{array}$ & \multicolumn{7}{|c|}{ t-test for Equality of Means } \\
\hline & $\mathrm{F}$ & \multirow[t]{2}{*}{$\mathrm{t}$} & \multirow[t]{2}{*}{ df } & \multirow[t]{2}{*}{$\begin{array}{l}\text { Sig. } \\
(2- \\
\text { tailed) }\end{array}$} & \multirow[t]{2}{*}{$\begin{array}{l}\text { Mean } \\
\text { Difference }\end{array}$} & \multirow[t]{2}{*}{$\begin{array}{l}\text { Std. Error } \\
\text { Difference }\end{array}$} & \multicolumn{2}{|c|}{$\begin{array}{l}\text { 95\% Confidence } \\
\text { Interval of the } \\
\text { Difference }\end{array}$} \\
\hline & & & & & & & Lower & Upper \\
\hline $\begin{array}{l}\text { Equal } \\
\text { variances } \\
\text { assumed }\end{array}$ & $1.319 \quad .255$ & 3.519 & 64 & .001 & 11.41818 & 3.24510 & 4.93536 & 17.90101 \\
\hline $\begin{array}{l}\text { Equal } \\
\text { variances } \\
\text { not } \\
\text { assumed }\end{array}$ & & 3.519 & 60.565 & .001 & 11.41818 & 3.24510 & 4.92827 & 17.90810 \\
\hline
\end{tabular}

As indicated in Table 13 above $\mathrm{t}(64)=3.519, \mathrm{p}=.001<.05$, the posttest mean of the experimental group and the control group is statistically significantly different. It is safe to state that the developed literature-based reading materials are effective and is suitable for EFL students at Indonesian Islamic universities. 


\section{Discussions}

Each unit of the developed literature-based reading materials presents related pictures, while some units contain a multimedia project like role play and poetry choral reading. The materials are in tuned with what call as a multimodal or creolized text. Accordingly, the use of various semiotic systems like language, pictures, gestures, and sound will make the materials a fascinating resource that adds vivacity to the EFL classroom activities.

The literature-based reading materials generally support the view that an interdisciplinary framework is needed to justify the use of literary texts in EFL classrooms (Bobkina, Dominguez, 2014: 249). Teaching literature as a means for teaching reading at Islamic universities interconnects three frameworks: literature, EFL, and Islamic educational tradition. What makes literature-based reading materials acceptable is that the incorporation of literary texts from western, Indonesian, and Islamic sources. Such incorporation can sensibly respond the issues of text ownership proposed by Singh (2015: 179) so as to reduce the tension that might emerge from such questions as which literature, whose text, whose context, whose world?

As argues that it is normal for a community to store their cultural values and cultural inventory, and spread them to their next generations, it is safe to state that the developed literature-based reading materials are plausible from the perspective of the cultural linguistics. The materials incorporate students' national and spiritual literary texts like Pasopati and Ilir-Ilir in addition to foreign texts like Narcissus and Sleeping Beauty. Such incorporation is another way of investing and conveying the students' cultural values and identity within EFL instruction.

The developed literature-based reading materials for Indonesian Islamic university might be reasonably connected with the challenges of teaching literature in other expanding circle countries. Hussein, et, al. (2016: 136), for instance, find that students' unfamiliarity with the social-cultural aspects of the text as well as their low level of language proficiency is the most obvious challenges of teaching literature in Saudi Arabia context. Another finding from Zhen (2012: 38) also reveals that exposing original texts without their simplified versions are not suitable for students with a limited command of English in China EFL context. Thus, by taking students' cultural elements into account and utilizing both simplified and original literary texts, the literature-based reading materials fit the needs of the particular type of educational setting like Indonesian Islamic university.

\section{Conclusion}

As the literature-based reading materials are developed in tune with research findings and theoretical review and are assessed by experts, practitioners, and students, it is appropriate for sophomore students of the English department at Islamic universities. Specifically, it is suitable for beginning readers and an intensive reading program. The use of the developed materials for the first year students of Islamic university is possible when the students have interests in reading literary texts and possess an adequate level of English mastery. Lecturer's practical consideration of students' needs and language 
proficiency should be a major factor in deciding the best moment to implement the developed materials.

\section{Bibliographic references}

ALWASILAH, A.C. 2014. Islam, Culture, and Education: Essays on Contemporary Indonesia. Bandung: PT Remaja Rosdakarya. ISBN 9789796924530

ASIA/PACIFIC CULTURAL CENTER FOR UNESCO (ACCU). 2001. Handbook: Adult Learning Materials Development at Community Level. Japan: Tokyo Colony. Available online: http://www.accu.or.jp/litdbase.

BAYAT, M. - JAMNIA, M.A.1994. Tales From the Land of the Sufis. Boston: Shambala. ISBN 359613966X

BOBKINA, J. - DOMINGUEZ, E. 2014. The use of literature and literary texts in the EFL classroom; between consensus and controversy. In: International Journal of Applied Linguistics \& English Literature, vol. 3, issue. 2, pp. 248-260. ISSN 22003452

BROSH, H. - MANSUR, L. 2013. Arabic Stories for Language Learners. Tokyo: Tuttle Publishing. ISBN 0804843007

COELHO, P. 1998. The Alchemist. San Francisco: Harper San Francisco. ISBN 0061122416

COLLIE, J. - SLATER, S. 1994. Literature in the Language Classroom: A Resource Book of Ideas and Activities. Cambridge: Cambridge University Press. ISBN 0521312248

COX, C. 2012. Literature-Based Teaching in the Content Areas. California: SAGE Publications, Inc. ISBN 9781412974936

CRESWELL, J.W. 2012. Planning, Conducting and Evaluating Quantitative and Qualitative Research (Fourth Edition). Boston: Pearson Education, Inc. ISBN 0131367390

CULLER, J. 2000. Literary Theory: A Very Short Introduction. Oxford: Oxford University Press. ISBN 0199691347

DEWI, N. 2016. Words' Wonder: Beginners' Guide to Literature. Yogyakarta: Sanata Dharma University Press. ISBN 9786026369208

DOECKE, B. 2013. Storytelling and professional learning. In: English in Australia, vol. 48, issue 2, pp.11-21. ISSN 0155-2147

http://www.poemhunter.com/poem/abou-ben-adhem/

HUSSEIN, E.T. - AL-EMAMI, A.H. 2016. Challenges to teaching English literature at the university of Hail: instructors' perspective. In: Arab World English Journal (AWEJ), vol. 7, issue 4, pp. 125-138. ISSN 2229-9327

KASSER, C. - SILVERMAN, A. 1986. Stories We Brought With Us: Beginning Readings for ESL. New Jersey: Prentice Hall. ISBN 0138501246

KATHEER, I. 2001. Stories of the Qur'an. Egypt: Dar Al-Manarah. ISBN 9776005136

KNAPPERT, J. 1997. Myths and Legends of Indonesia. Singapore: Heinemann Educational Books (Asia) Ltd. ISBN 9999238033

KNAUTH, D.C. 2010. Performing Islam through Indonesian Popular Music 20022007. A doctoral, University of Pittsburgh.

KUMARAVADIVELU, B. 2012a. Language Teacher Education for a Global Society. New York: Routledge. ISBN 9780415877374

KUMARAVADIVELU, B. 2012b. Individual Identity, Cultural Globalization, and Teaching English as an International Language: The Case for an Epistemic Break. In ALSAGOFF, L., ET.Al., (Eds.), Principles and Practices for Teaching English as an International Language pp. 9-27. New York: Routledge. ISBN 9780415891660

XLinguae, Volume 13, Issue 3, June 2019, ISSN 1337-8384, eISSN 2453-711X 
LAZAR, G. 2009. Literature and Language Teaching. Cambridge: Cambridge University Press. ISBN 9780521406512

MALEY, A. 2008. Extensive Reading: Maid in Waiting. In TOMLINSON, B. (ed.), English Language Learning Materials: A Critical Review pp.133-156. London: Continuum International Publishing Group. ISBN 9780826493507

MALEY, A. 2012. Literature and Language Teaching. In ALSAGOFF, L., ET.AL., (Eds.), Principles and Practices for Teaching English as an International Language (p. 299-317). New York: Routledge. ISBN 9780415891660

MELLO, AD. 2003. The Prayer of the Frog Volume I. Gujarat: Gujarat Sahitya Prakash. ISBN 8187886250

MOODY, H.L.B. 1971. The Teaching of Literature. London: Longman Group Ltd. ISBN 0582526027

MUTHARI, A.H.W. 2016. Kembali ke Akar Kembali ke Sumber. Yogyakarta: DIVA Press. ISBN 9786023911530

NATION, I.S.P. - MACALISTER, J. 2010. Language Curriculum Design. New York: Routledge. 0415806054

PUSPITASARI, E. 2016. Literature-based learning to build students' vocabulary. In: Journal of Foreign Language, Teaching \& Learning, vol. 1, issue 1, pp. 49-60. ISSN 2580-2070

QOMAR, M. 2012. Fajar baru Islam Indonesia?: kajian komprehensif atas arah sejarah dan dinamika intelektual Islam nusantara. Bandung: PT Mizan Pustaka. ISBN 978-979-433-715-8

RACKHMAN, A. 2014. Grimm's Fairy Tales. New York: Fall River Press. ISBN 1454912340

RAKHMAT, J. 2009. The Road to Muhammad. Bandung: PT Mizan Pustaka \& Muthahhari Press. ISBN 9789794334959

RATNA, N. K.2008. Postkolonialisme Indonesia: Relevansi sastra. Yogyakarta: Pustaka Pelajar. ISBN 6028055328

RETNANINGDYAH, P. 2010. Developing literature-based materials for EFL classroom at secondary level by using personal growth model. Available online: https://www. academia.edu/3266479/Developing_Literature-based_EFL_Classroom. RICHARDS, J.C. 2001.Curriculum Development in Language Teaching. Cambridge: Cambridge University Press. ISBN 0521804914

RICHARDS, J.C. 2015. Key Issues in Language Teaching. Cambridge: Cambridge University Press. ISBN 110745610X

ROSENBLATT, L. M. 2005. From literature as exploration and the reader, the text, the poem. In: Voices From the Middle, vol. 12, issue 3, pp. 25-30. ISSN 1074-4762

RUMI, J. 2004. The Essential Rumi: New Expanded Edition. New York: HarperOne. ISBN 0062509594

SHAH, I. 1967. Tales of the Dervishes. New York: E.P. Dutton \& Co., Inc. 9781784790721

SHOWALTER, E. 2012. Teaching Literature. Malden: Blackwell Publishing. ISBN 0631226249

SINGH, R. B. 2015. Teaching world literature in English: inside the US, outside the Whale. In: Ariel: a review of international English literature, vol. 46, issue 1-2, pp. 175-210. ISSN 0004-1327

SOERATNO, S.C. 2005. Sastra dalam Wawasan Pragmatis: Tinjauan atas Asas Relevansi dalam Pembangunan Bangsa. In TANTHOWI, P. U. (Ed.). Begawan Muhammadiyah, pp. 343-387. Jakarta: PSAP Muhammadiyah. ISBN 9799830559

STERN, S.L. 1991. An Integrated Approach to Literature in ESL/EFL. In CELCEMURCIA, M. (Ed.), Teaching English as a Second or Foreign Language pp. 328-346. Boston: Heinle \& Heinle Publishers. ISBN 0066326362

TOH, G. 2000. Voices of Southeast Asia: An Anthology of Southeast Asian Short Stories. Singapore: SEAMEO Regional Language Centre. ISBN 9971740664 
VACCA, J.A.L. - VACCA, R.T., ET.AL. 2006. Reading and Learning to Read. Boston: Allyn \& Bacon. ISBN 0205431542

VARDELL, S.M. - HADAWAY, N.L. - YOUNG, T.A. 2006. Matching books and readers: selecting literature for English learners. In: The Reading Teacher, vol. 59, pp. 734-741. ISSN 1936-2714

ZHEN, C. 2012. Characteristics and strategies of literature teaching in the EFL context in China. In: International Journal of Electronics and Communication Engineering, vol. 5, issue. 3, pp. 35-43. ISSN 0974-2166

ZUCHDI, D. ET.AL. 2013. Pendidikan Karakter: Konsep Dasar dan Implementasi di Perguruan Tinggi. Yogyakarta: UNY Press. ISBN 9798418638

Words: 6911

Characters: 46226 (25,70 standard pages)

Doctor of English Education Dedi Irwansyah

State Islamic Institute of Metro (IAIN Metro)

Jl. Ki. Hajar Dewantara Kampus 15 A Metro Lampung 34111

Indonesia

dedi.irwansyah@student.uny.ac.id

Doctor of Indonesian Literature Burhan Nurgiyantoro

Professor of the Faculty of Language and Arts

Department of Language Education Science

Yogyakarta State University

Jl. Colombo No.1 Karangmalang, Sleman, Yogyakarta

Indonesia

burhan@uny.ac.id

Doctor of English Education Sugirin

Professor of the Faculty of Language and Arts

Department of Language Education Science

Yogyakarta State University

Jl. Colombo No.1 Karangmalang, Sleman, Yogyakarta

Indonesia

sugirin@uny.ac.id 
Appendices: Unit example of the literature-based reading materials for EFL students at Indonesian Islamic universities

\begin{tabular}{|c|c|c|}
\hline Materials & : & $\begin{array}{l}\text { Unit 5: Ilir-Ilir } \\
\text { Topic: self-empowerment } \\
\text { Source: Indonesian culture }\end{array}$ \\
\hline Objectives & $:$ & $\begin{array}{l}\text { L2: Organizing, analyzing, and synthesizing the } \\
\text { information which has been explicitly stated in } \\
\text { the text. } \\
\text { L4: Judging and deciding on the values and worth } \\
\text { related to the texts } \\
\text { L5: Giving psychological and aesthetical responses } \\
\text { toward the texts }\end{array}$ \\
\hline Tasks & & $\begin{array}{l}\text { Pre-reading } \\
\text { Exposing the cultural background of the text. } \\
\text { While-reading } \\
\text { Organizing words (L2); Discussing symbolic } \\
\quad \text { meaning (L3). } \\
\text { Post-reading } \\
\text { Discussing the values found in the text (L4); } \\
\text { Demonstrating the text (L5). }\end{array}$ \\
\hline Indicators & $:$ & $\begin{array}{l}\text { Students are able to: (1) fill in the correct words into } \\
\text { a given text; (2) note down the words or phrases } \\
\text { with symbolic meaning; (3) identify the character } \\
\text { education values; and (4) read the poem chorally. }\end{array}$ \\
\hline Worksheet & . & -- \\
\hline Assessment & $:$ & Cloze task \\
\hline Times & & $90^{\prime}$ \\
\hline
\end{tabular}




\section{Unit 5}

\section{Ilir-Ilir}

\section{By Sunan Kalijaga}

The poem is taken from Doecke, B. (2013). Storytelling and professional learning [Versi elektronik]. English in Australia Volume

48 Number 2, 11-21, and Knauth, D.C. (2010). Performing Islam

through Indonesian popular music 2002-2007. A doctoral, University of Pittsburgh.

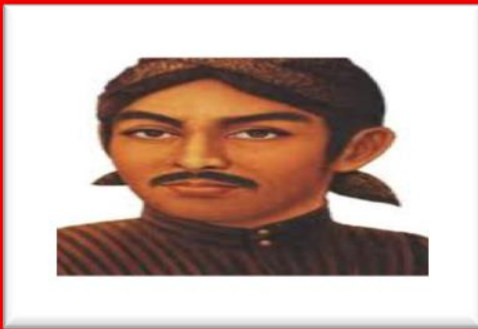

The illustration of Sunan Kalijaga is taken from: id.wikipedia.org

\section{PRE-READING}

\section{Task 1: Exposing the cultural background of the text}

Ilir-ilir is a famous song written by Sunan Kalijaga in the 14th century. Sunan Kalijaga is one of the nine saints (Wali Sanga) of Javanese Islam. Qomar (2012: 35) argues that the song is about a commitment of a Muslim or a person newly converted to Islam to practicing Islamic teachings.

Before reading the text of Ilir-ilir, think about these questions:

1. Are you familiar with the song?

2. In what contexts would people sing the song?
a. $\ldots .$.
b.
c. $\ldots$.

3. Do you think the message of the song still relevant to nowadays situation? 
Rearrange the following scrambled stanzas.

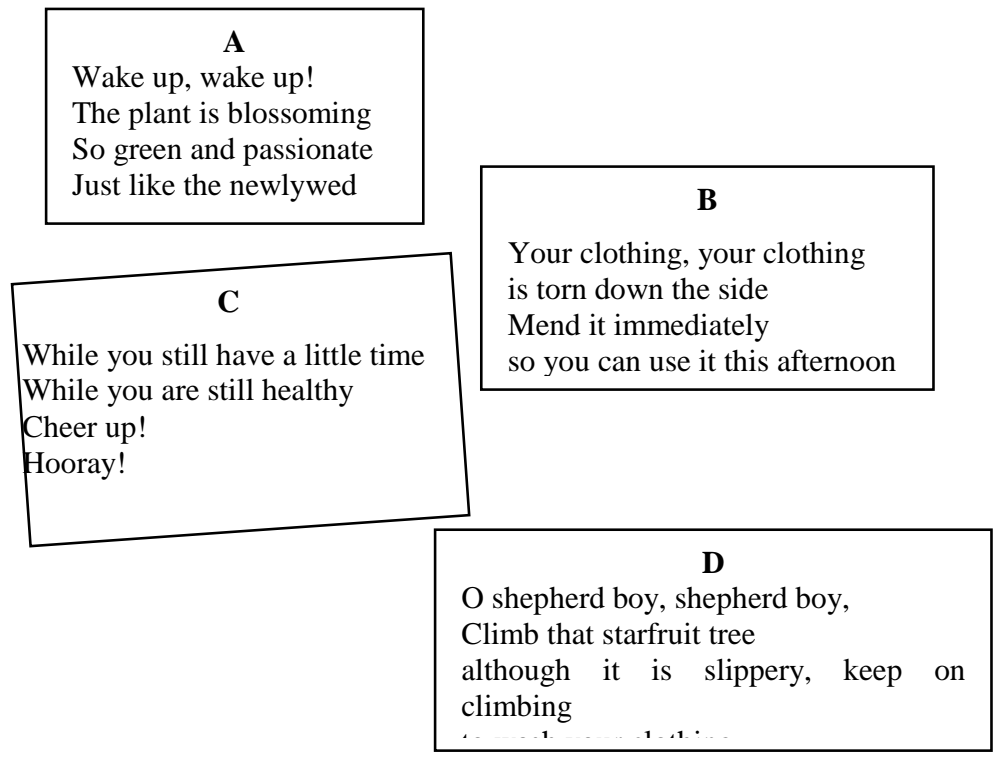

\section{Task 2: Organizing words}

You are going to read an interpretation of Ilir-ilir. With a partner, complete the interpretation using the words in the box.

\begin{tabular}{|lllll|}
\hline $\begin{array}{l}\text { Javanese } \\
\text { easy }\end{array}$ & $\begin{array}{l}\text { mistakes } \\
\text { prepare }\end{array}$ & $\begin{array}{l}\text { symbolize } \\
\text { lazy }\end{array}$ & $\begin{array}{c}\text { time } \\
\text { happy }\end{array}$ & \\
\end{tabular}

In reading the lyrics of Lir-ilir one might want to know some symbolic meanings.

First, Lir-ilir is a .... phrase which means wake up. It implies that a Muslim should not be....

Second, the expression of 'the plant is blossoming' .... 'Islamic faith'. A Muslim should work hard to look after the faith.

Third, those who can maintain the faith will be... Such happiness is represented by the phrase of 'the newlywed'.

Fourth, 'shepherd boy' represents a Muslim that should look after his/her heart.

Fifth, in order to maintain the heart successfully, a Muslim should practice the five .... of Islam which is symbolized through 'star fruit tree'.

Sixth, practicing the five pillars is not .... as it is symbolized through the word 'slippery'. 
Seventh, the practice of the five pillars is aimed at cleansing the clothing. The word 'clothing' symbolizes conduct or piety. The 'conduct' or 'piety' might not free from .... A Muslim should fix the mistakes he/she made immediately.

Eighth, the .... 'this afternoon' might symbolize 'death'.

Ninth, as death could come anytime, a Muslim should .... himself while he or she still has .... and is still healthy.

\section{READING THE ORIGINAL VERSION}

Lir-ilir

Tandure wus sumilir

Tak ijo royo-royo

Tak sengguh temanten anyar

Cah angon, Cah angon

Penekno blimbing kuwi

Lunyu-lunyu penekno

Kanggo mbasuh dodot-iro

Dodot'iro dodot'ro

Lumintir bedah ing pinggir

Dondomono jlumantono

Kanggo sebo mengko sore

Mumpung jembar kalangane

Mumpung padang rembulane

Yo surako

Surak: Hiyyoo
[Vocables signifying ocean waves]

The plantation is in full growth

and the foliage is all green.

It is a gift befitting the newlyweds.

Young shepherd child

climb that starfruit tree

even though it is slippery

it will help cleanse our heart,

Inside my heart

One side is torn.

Sew it... mend it...

for the wedding celebration at noon.

While the open field reveals our

blessings,

While the night is bright from the full

moon,

Let $u$ sive praise and rejoice.

Give praise and rejoice.

(Translated by Knauth , 2010:173)

\section{Task 3: Discussing symbolic meaning}

1. Write down two translations of kanggo sebo mengko sore.

2. What might the expression of kanggo sebo mengko sore symbolize?

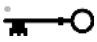




\section{POST-READING}

\section{Task 4: Discussing the values found in the text}

What 'character education values' might you learn from the lyrics of Ilir-ilir? You may tick more than once. You may also propose your own values if any.

$\square$ Being friendly
$\square$ Being helpful
$\square$ Being religious
$\square$ Being self-dependent
$\square$ Discipline
$\square$ Hard work
$\square$ Honesty
$\square$ Modesty
$\square$ Responsibility
$\square$ The love for the peace

\section{Task 5: Demonstrating the text}

Work in groups of 4-5 to perform a choral reading. You can read a line of the song individually, in pairs, on in groups. You might want to make limited use of movement, facial expressions, and gestures.

You might want to see related video of Lir Ilir on the following link: https:youtu.be/Kz2M_7tv_2M 